\title{
The PHOTON explorations: sixteen activities, many uses
}

Judith Donnelly, Kathryn Amatrudo, Kathleen Robinson, Fenna Hanes

Judith Donnelly, Kathryn Amatrudo, Kathleen Robinson, Fenna Hanes, "The PHOTON explorations: sixteen activities, many uses," Proc. SPIE 9289, 12th Education and Training in Optics and Photonics Conference, 92892H (17 July 2014); doi: 10.1117/12.2070736

EDIE Event: 12th Education and Training in Optics and Photonics Conference, 2013, Porto, Portugal 


\title{
The PHOTON Explorations: Sixteen Activities, Many Uses
}

\author{
Judith Donnelly*a $^{*}$ Kathryn Amatrudo ${ }^{\text {b }}$, Kathleen Robinson ${ }^{c}$, Fenna Hanes ${ }^{\text {d }}$ \\ a Three Rivers Community College, 574 New London Turnpike, Norwich, CT 06030 \\ ${ }^{\mathrm{b}}$ The Optical Society of America, 2010 Massachusetts Ave NW, Washington, DC 20036 \\ ${ }^{\mathrm{c}}$ SPIE, PO Box 10, Bellingham, WA 98227-0010 \\ ${ }^{\mathrm{d}}$ New England Board of Higher Education, 45 Temple Place, Boston, MA 02111
}

\begin{abstract}
The PHOTON Explorations were adapted from favorite demonstrations of teacher participants in the PHOTON projects of the New England Board of Higher Education as well as Hands-on-Optics activities and interesting demonstrations found on the web. Since the end of project PHOTON2 in 2006, the sixteen inquiry-based activities have formed the basis for a hands-on "home lab" distance- learning course that has been used for college students, teacher professional development and corporate training. With the support of OSA, they have been brought to life in a series of sixteen short videos aimed at a middle school audience. The Explorations are regularly used as activities in outreach activities for middle and high school students and are introduced yearly to an international audience at an outreach workshop at SPIE's Optics and Photonics meeting. In this paper we will demonstrate the Explorations, trace their origins and explain the content. We will also provide details on the development of the Exploration videos, the online course, and outreach materials and give statistics on their use in each format. Links to online resources will be provided.
\end{abstract}

Keywords: Education, outreach, online learning, Optics4Kids, hands-on, middle school, OSA Video Library, PHOTON Projects

\section{ORIGIN OF THE EXPLORATIONS}

The PHOTON Projects of the New England Board of Higher Education (NEBHE) were funded through the Advanced Technological Education (ATE) program of the National Science Foundation from 1995 through 2009. The first of these, the Fiber Optic Technology Education Project (FOTEP), provided laboratory equipment and a series of professional development workshops to more than 40 high school and college instructors to enable them to teach fiber optics in their own classrooms. The following three PHOTON projects expanded on the work of FOTEP in geographical area, by including teachers from Maine to Hawaii, and in the industry sectors involved, including not just fiber optics but all of optics/photonics. PHOTON provided high quality laboratory kits to middle schools, high schools and colleges plus professional development workshops to teachers and faculty throughout New England, and PHOTON2 expanded the PHOTON's reach through professional development by distance learning across the United States. The PHOTON PBL (Problem-Based Learning) project is a departure from strictly content-based curriculum development in that it also addresses the issue of how students actually learn. PHOTON PBL and the two PBL projects that have followed use a research-based approach and work closely with industry and research university partners to develop "real-world" interactive "Challenges" (case studies) that teach problem solving skills and content at the same time. Table 1 provides a summary of the key activities and outcomes of the PHOTON Projects.

PHOTON (2000-2003) was the only one of the projects to include middle school teachers, usually grades 6-8 although some middle schools also include grade 5. Middle school teachers felt the PHOTON materials would make good demonstrations in their classrooms, but the complexity of both concepts and materials made them less suitable for handson experiments with younger students. During one of the summer workshops, the PHOTON management team invited teachers to join them in demonstrating some of their own favorite labs and hands-on activities, especially those that used simple, inexpensive and easy to find materials. Demonstrations such as "The Magic (polarization) Box" and "What Color is a Tomato?" were among the first experiments to be collected as the PHOTON Explorations. Some demonstrations were rejected because of complexity or expense of equipment and supplies, difficulty in assembling parts to produce reliable results or safety issues. For example, one interesting demonstration was to create a "silver" egg by coating a white egg with soot from a candle and placing the sooty egg in water. The desired effect is produced when the air film trapped in the soot reflects light and makes the egg appear shiny silver. However, the demonstration was just too messy to be included. A favorite of workshop participants was a demonstration of wave behavior accomplished by tying a rope to the blade of a vibrating saber saw, but the experiment was judged too dangerous for the average middle school classroom. Other activities, like those involving Slinky ${ }^{\circledR}$ toys, were not included because they are well known among physical science teachers with many experiments already available from a variety of sources.

\footnotetext{
${ }^{*}$ jdonnelly@trcc.commnet.edu Phone: 860.885.2353

12 th Education and Training in Optics and Photonics Conference, edited by

Manuel F. P. C. Martins Costa, Mourad Zghal, Proc. of SPIE Vol. 9289, 92892H

(C) 2014 SPIE, OSA, IEEE, ICO · doi: 10.1117/12.2070736
} 
Table 1. Summary of Key Activities and Outcomes of the PHOTON Projects ${ }^{1}$

\begin{tabular}{|c|c|c|c|}
\hline Project & Participants & Activities & Major outcomes \\
\hline FOTEP & $\begin{array}{l}\text { More than } 40 \text { high } \\
\text { school \& college } \\
\text { faculty from New } \\
\text { England }\end{array}$ & $\begin{array}{l}\text { Materials development: } \\
\text { - Fiber optic lab kit and instructional } \\
\text { materials } \\
\text { Professional development: } \\
\text { - Introductory 2-day workshop } \\
\text { - Two week-long summer workshops } \\
\text { for participants with industry inclusion }\end{array}$ & $\begin{array}{l}\text { - Fiber optic units taught by program } \\
\text { participants grew from six to } 26 \text {. } \\
\text { - Fiber optic courses taught in New England } \\
\text { colleges grew from three to seven. } \\
\text { - A.S. degree program in fiber optics was } \\
\text { established at a community college in CT. } \\
\text { - Over } 60 \% \text { of FOTEP faculty participants } \\
\text { built contacts and partnerships with local fiber } \\
\text { optics businesses. }\end{array}$ \\
\hline PHOTON & $\begin{array}{l}39 \text { middle school, } \\
\text { high school and } \\
\text { college faculty, } \\
\text { paired by } \\
\text { geographical } \\
\text { region }\end{array}$ & $\begin{array}{l}\text { Materials developed: } \\
\text { - Lab kit valued at } \$ 5000 \text { with } \\
\text { instructions for } 25 \text { experiments } \\
\text { - Eight instructional modules } \\
\text { - } 13 \text { Explorations for middle school } \\
\text { labs } \\
\text { Professional development: } \\
\text { - Summer workshops for } \\
\text { teachers/faculty and guidance counselors } \\
\text { - Showcase workshop }\end{array}$ & $\begin{array}{l}\text { - Industry-mentored email listserv established } \\
\text { for technical support, still active in } 2013 \\
\text { - Three community colleges established } \\
\text { industry partnerships: materials donations, co- } \\
\text { op jobs and industry scholarships for students, } \\
\text { and industry participation on college advisory } \\
\text { committees. } \\
\text { - } 14 \text { high schools established industry } \\
\text { partnerships including part-time jobs for } \\
\text { students, plant tours, and industry participation } \\
\text { on school advisory boards. } \\
\text { - High schools and local community colleges } \\
\text { created stronger bonds } \\
\text { - More than } 4900 \text { students exposed to } \\
\text { photonics }\end{array}$ \\
\hline PHOTON2 & $\begin{array}{l}38 \text { high school and } \\
\text { colleges from } \\
\text { "regional alliances" } \\
\text { across the U. S. }\end{array}$ & $\begin{array}{l}\text { Materials development: } \\
\text { - 15-chapter textbook, Light- } \\
\text { Introduction to Optics and Photonics. } \\
\text { - Modified PHOTON laboratory kit and } \\
\text { experiments } \\
\text { - Career guidance resource materials for } \\
\text { career and guidance counselors. } \\
\text { Professional Development: } \\
\text { - Web-based professional development } \\
\text { course for optics/photonics } \\
\text { - Educator internships } \\
\text { - Showcase workshop }\end{array}$ & $\begin{array}{l}\text { - Increased industry involvement through local, } \\
\text { paid summer internships in the photonics } \\
\text { industry during } 2005 \text { and } 2006 \text { for teachers and } \\
\text { counselors. } \\
\text { - Increased networking with industry and } \\
\text { professional societies through final showcase } \\
\text { workshop in } 2006 \text { held at SPIE's O\&P } \\
\text { Conference. } \\
\text { - Regional bonds between high schools and } \\
\text { community colleges strengthened } \\
\text { - International cooperation with partners in } \\
\text { Romania }\end{array}$ \\
\hline $\begin{array}{l}\text { PHOTON } \\
\text { PBL }\end{array}$ & $\begin{array}{l}43 \text { high school and } \\
\text { college instructors } \\
\text { participated in two } \\
\text { summer workshops } \\
\text { including two } \\
\text { participants from } \\
\text { Romania }\end{array}$ & $\begin{array}{l}\text { Materials development: } \\
\text { - } 8 \text { web-based multi-media "Challenges" } \\
\text { (case studies) with industry and research } \\
\text { university partners } \\
\text { - PBL implementation guide } \\
\text { Professional development: } \\
\text { - Two summer workshops }\end{array}$ & $\begin{array}{l}\text { - } 8 \text { Challenge aligned to U.S. academic } \\
\text { standards } \\
\text { - Challenges field tested by more than } 500 \\
\text { students at } 12 \text { high schools and } 6 \text { colleges }\end{array}$ \\
\hline
\end{tabular}

Additional Explorations were developed during the PHOTON2 project (2003-2006); these were adapted from workshops or projects such as Hands-On Optics ${ }^{2}$ or they were created specifically for classroom presentations or outreach. For example, "The Magic Lens" was demonstrated by a science teacher in Hartford, CT at a workshop for high school students. The students observed what happened when parallel rays from a laser light box were incident on two lenses of the same shape that were submerged in a fish tank of water. One lens caused the rays to converge (as many students expected), but the other, an "air lens", made the rays diverge. Students were challenged to use their knowledge of refraction to explain the difference in lens behavior.

By 2009, the Explorations comprised 16 activities with a record of many years of classroom and outreach success. The materials required are simple and inexpensive: the Optical Society of America's OSA Optics Discovery Kit, a low-cost collection of components available through Edmund Optics, Inc., and materials such as cardboard tubes, aluminum foil or a discarded recordable CD. An inexpensive laser pointer and small flashlight complete the supplies needed to study 
many topics in an introductory optics course. In 2010 all of the written instructions were edited into an inquiry-based format. Each Exploration begins with an engaging "Key Question" that students answer by working through hands-on activities, making and recording guided observations and drawing conclusions. The activities can be completed in less than an hour, making them suitable for both classroom use and outreach workshops. The complete list of Explorations and the Key Questions is in Table 2. The Explorations are available on the NEBHE web site. ${ }^{3}$

Table 2. List of Explorations

\begin{tabular}{|c|c|c|}
\hline Exploration Name & Key Question & Activity \\
\hline Exploring Light Spectra & $\begin{array}{l}\text { Can you tell what colors } \\
\text { (wavelengths) are produced by a light } \\
\text { source by looking at the light with } \\
\text { your unaided eye? }\end{array}$ & $\begin{array}{l}\text { Make a "spectroscope" using a cardboard tube and } \\
\text { diffraction grating (or CD with coating removed) } \\
\text { and look at emission spectra of readily available } \\
\text { light sources. }\end{array}$ \\
\hline What Color is a Tomato? & $\begin{array}{l}\text { Can your eyes be fooled by the color } \\
\text { of a light source? In what careers is the } \\
\text { color of illumination important? }\end{array}$ & $\begin{array}{l}\text { Look at brightly colored objects under different } \\
\text { color lighting. A small tomato under blue light } \\
\text { looks like a plum; or use small colored candies } \\
\text { with a variety of color LED lights or a flashlight } \\
\text { and gelatin filters }\end{array}$ \\
\hline Exploring Pinhole Images & $\begin{array}{l}\text { How can you make an image (picture) } \\
\text { with just a cardboard box } \\
\text { and a pinhole? }\end{array}$ & $\begin{array}{l}\text { Create and view a pinhole image from a small } \\
\text { carton. The pinhole is made with a needle in a } \\
\text { piece of aluminum foil, the screen on the opposite } \\
\text { side can be waxed or tracing paper. }\end{array}$ \\
\hline Exploring Reflection & $\begin{array}{l}\text { How can you see a "transparent" } \\
\text { object? }\end{array}$ & $\begin{array}{l}\text { Make a beaker or test tube disappear in vegetable } \\
\text { oil. }\end{array}$ \\
\hline Laser Target Shoot & How does reflection work? & $\begin{array}{l}\text { Arrange a laser and mirror (or multiple mirrors) to } \\
\text { hit a target with the beam. Laser and target are } \\
\text { stationary, only the mirror(s) can be moved. }\end{array}$ \\
\hline Exploring Refraction & $\begin{array}{l}\text { How do lenses change the path of } \\
\text { light? }\end{array}$ & $\begin{array}{l}\text { Explore refraction with plane and curved surfaces } \\
\text { using a laser pointer and blocks of stiff gelatin. }\end{array}$ \\
\hline $\begin{array}{l}\text { Exploring Lenses-the Magic } \\
\text { Lens }\end{array}$ & $\begin{array}{l}\text { Can you make a lens out of air and use } \\
\text { it in water? How will it behave } \\
\text { differently from a glass lens used in } \\
\text { air? }\end{array}$ & $\begin{array}{l}\text { Make a hollow lens of two watch glasses } \\
\text { cemented together to create an "air lens" and } \\
\text { observe its operation in a water tank. Compare to } \\
\text { a solid glass lens with the same shape. }\end{array}$ \\
\hline Exploring Diffraction & $\begin{array}{l}\text { How can you use a laser to measure } \\
\text { the thickness of your hair? }\end{array}$ & $\begin{array}{l}\text { Tape a hair over the output of a laser pointer and } \\
\text { use diffraction to measure the diameter of the hair. }\end{array}$ \\
\hline $\begin{array}{l}\text { Exploring Rayleigh's Criterion } \\
\text { and Resolution }\end{array}$ & $\begin{array}{l}\text { How close together can small dots be } \\
\text { printed and still be seen as separate } \\
\text { dots? Does it depend on the color of } \\
\text { the dots? }\end{array}$ & $\begin{array}{l}\text { Print out rows of equally spaced red and blue dots } \\
\text { as observe them as the distance from observer to } \\
\text { dots decreases. Which color dots merge into a line } \\
\text { first? }\end{array}$ \\
\hline Exploring Polarization & $\begin{array}{l}\text { What is polarized light? How can you } \\
\text { make polarized light? }\end{array}$ & $\begin{array}{l}\text { A series of activities to explore transmission axes, } \\
\text { polarization by reflection, polarization of the blue } \\
\text { sky, and birefringence }\end{array}$ \\
\hline The Magic Box & $\begin{array}{l}\text { Can you use light to make a magic box } \\
\text { with a "wall that isn't there"? }\end{array}$ & $\begin{array}{l}\text { Using four polarizers mounted on a cardboard } \\
\text { box, create the illusion of a wall. Pass a stick or } \\
\text { pencil through the wall to illustrate the illusion. }\end{array}$ \\
\hline Polarized Light Art & $\begin{array}{l}\text { Can you use polarized light to make a } \\
\text { colorful picture? }\end{array}$ & $\begin{array}{l}\text { Place pieces of cellophane between two polarizers } \\
\text { and create an artistic presentation. }\end{array}$ \\
\hline Exploring Scattering & Why is the sky blue? & $\begin{array}{l}\text { Shine a flashlight through a fish tank of water } \\
\text { with a few drops of milk. Observe the color of the } \\
\text { beam from the side and end of the tank. }\end{array}$ \\
\hline Exploring Laser Beams & $\begin{array}{l}\text { How is a laser beam different from a } \\
\text { flashlight beam? }\end{array}$ & $\begin{array}{l}\text { Activities to explore divergence, } \\
\text { monochromaticity and laser speckle. Experiments } \\
\text { are done with a laser pointer and a flashlight to } \\
\text { illustrate the difference. }\end{array}$ \\
\hline $\begin{array}{l}\text { Exploring Fluorescence and } \\
\text { Phosphorescence }\end{array}$ & $\begin{array}{l}\text { How does fluorescence differ from } \\
\text { phosphorescence? }\end{array}$ & $\begin{array}{l}\text { Look at fluorescent materials (whitening } \\
\text { detergent, toothpaste, etc) under UV light. Shine } \\
\text { both a red laser pointer and a flashlight on } \\
\text { phosphorescent material (available in toy and } \\
\text { novelty shops) and explain the difference in } \\
\text { response. }\end{array}$ \\
\hline $\begin{array}{l}\text { Exploring UV Light and } \\
\text { Sunscreen Lotion }\end{array}$ & $\begin{array}{l}\text { How well does sunscreen protect } \\
\text { against UV light? }\end{array}$ & $\begin{array}{l}\text { Expose UV color change beads (available on the } \\
\text { web) to sunlight with and without sunscreen. }\end{array}$ \\
\hline
\end{tabular}


Since professional development follow-on technical support and outreach activities are still ongoing, new Explorations may be added to the collection as time permits. For example, work is proceeding on a developing lower cost version of the Hands-on-Optics kaleidoscope activity that has become a regular feature of outreach workshops.

\section{EXPLORATIONS FOR HANDS-ON ONLINE LEARNING}

One of the earliest uses of some of the activities that later became Explorations was as the hands-on component of an online distance learning course used in a certificate program at Three Rivers Community College (TRCC). Through a grant from the Connecticut Distance Learning Consortium in 2001, TRCC hired faculty to develop online courses in telecommunications, specifically, fiber optic technology. In 2003, TRCC contracted with 3M Optical Transport Systems (then of West Haven, CT) to deliver a mostly online basic fiber optic certificate program to all eighteen of the company's employees. Because 3M wanted a hands-on approach, simple, easy-to-perform experiments were developed for the certificate's optics course, Photonics Concepts. (The labs for the fiber optics course were conducted at the 3M facility using their state of the art equipment.) Each student received a laser pointer, a small focusable flashlight and an OSA Optics Discovery kit. The hands-on experiments included viewing emission spectra, the law of reflection, refraction and Snell's law, single-slit diffraction and basics of polarization. Students were required to make observations, take and analyze data and draw conclusions. $3 \mathrm{M}$ employees often met during their lunch hour to work on the labs together, drawing on the expertise of company engineers as mentors. Nine of the 18 students who began the program completed the entire four-course certificate.

The TRCC distance learning optics course provided the basic content for the PHOTON2 online course that was offered to two cohorts of high school and college teachers in 2004 and 2005. The TRCC course was completely redesigned for PHOTON2 with the assistance of consultants from the University of Connecticut's Neag School of Education to utilize research-based pedagogy appropriate to adult learners in a professional development course. Unlike the instructorcentered model of the original course where dialog was mainly between individual students and the instructor, the redesigned course was guided by the five principles of adult learning, namely that learning must be: ${ }^{4}$

- active, including hands-on, reflection, and discussion with peers as well as instructor feedback

- continuous, allowing students sufficient time to process material rather than "covering" a large number of topics

- coherent, linking concepts to real-world problems

- collaborative, working on group projects and sharing results through online discussions, and

- self regulated, including goal setting, time management, and reflection to help students understand their own learning process to become effective lifelong learners.

The basic principle of the PHOTON2 online course model was that instruction must establish a clear link between optics content and its application in the classroom. In practice this was accomplished by dividing the material into modules with each module centered around a hands-on laboratory done alone or collaboratively if teachers were geographically close. After completing the activity, teachers engaged in guided threaded discussions with each other and the course instructor to elucidate the physical principles involved, make suggestions for improving the activity and plan for teaching the topic in their own classrooms. Although each school received a lab kit with both science lab and industryquality equipment for the hands-on component, some Explorations were also used to complement the complex experiments with simpler and more economical activities.

Additional grant funding allowed the PHOTON2 online course to be delivered through TRCC in 2007 to approximately 20 additional high school and college faculty who were not part of the original project. Because not all participants in this group had access to a PHOTON2 kit, the hands-on portion of the course allowed participants to choose between a sophisticated (PHOTON2) experiment and the equivalent lower cost Exploration. Participants were encouraged to discuss the difference between the two approaches and decide which would be better for their own students.

The online course continues to be offered at TRCC where it is marketed for industry incumbent worker training as well as matriculated college students. Now called Introduction to Light and Lasers, the course uses the Explorations for hands-on activities in each of ten modules encompassing laser safety, light sources, geometric and wave optics. Each module begins with several key questions that students answer through readings, web applets, tutorials and working through one of the Explorations and comparing and contrasting the results of their experiment with those of their peers. Students successfully completing the course receive four college credits that can be applied to the Laser and Fiber Optic Technology associate degree or certificate. 


\section{EXPLORATIONS FOR OUTREACH}

With partner organization EASTCONN, a Connecticut Regional Educational Service Center, TRCC has been offering outreach to high school students and fifth graders (10-11 year-old students) since 2006. The visible spectrum, reflection and refraction are topics in the fifth grade Connecticut state science standards, and the Explorations that address these topics are used both in visits to fifth grade classrooms and when the students participate in field trips to the TRCC optics labs. Although the number of participating fifth graders varies from year to year, most years TRCC staff, OSA and SPIE Chapter members, and EASTCONN introduce optics through the Explorations to over 200 young students. Workshop effectiveness is evaluated through discussions with teachers and written feedback from students after they return to their classrooms. Typical feedback in 2013 indicated students absorbed at least some of the lesson content that was presented.

- II learned a lot about lasers. The ultraviolet activity was fun. I learned that ultraviolet light can give you a sunburn. The ultraviolet light is also known as a blacklight. When you wipe detergent on paper then put it under a black light it glows. It is really cool!"

- II loved our group activity, it was called hit the target. I learned that mirrors direct light. I also learned that light travels really fast. The most important thing I learned is that light travels really straight."
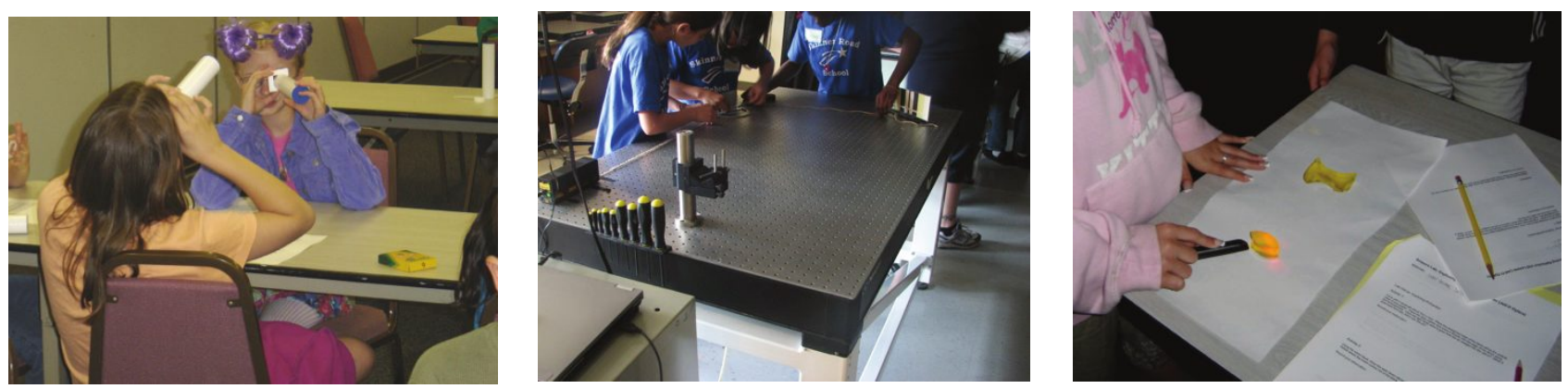

Figure 1. Fifth grade students learn optics through (left) Exploring Light Spectra (middle) Laser Target Shoot and (right) Exploring Refraction (gelatin optics).

High school Laser Camp focuses on college and careers in technology in general and optics/photonics in particular. Workshops include teambuilding among students from rural and city high schools and an exploration of college and career pathways. Exploring Polarization and Laser Target Shoot (with multiple mirrors) are popular workshops for this group. The activities are tailored for the older high school audience to include industry applications of the optics concepts presented. For example, examining students' eyeglasses between crossed polarizers leads to a discussion of the use of polarized light for stress testing. For an application of reflection, students examine the beam delivery system of a 45-watt $\mathrm{CO}_{2}$ laser engraver and then use the system to create individualized wooden key tags. Pre and post testing indicates that the workshops have been very successful at introducing basic optics/photonics concepts and, more important, teaching students about career opportunities available with an associate degree in a technology program.

After learning of the success of the PHOTON Explorations as an outreach tool, SPIE decided to run its first "Optics Outreach Magic" workshop at its Optics and Photonics meeting in 2009 as a part of its mission to encourage community outreach, increase awareness of the field and provide assistance and inspiration to teachers. Since that time the course has been a consistent hit with participants, receiving high ratings and having strong attendance. The 3-hour workshop is based on eight or nine of the PHOTON Explorations. Participants, who are mostly SPIE student chapter members from around the world and a handful of industry professionals, work through each of the hands-on activities creating several items to take home along with complete instructions and suggestions for finding supplies. Participants have commented that the workshop provides "Great affordable outreach ideas", "Very good material and ideas for what you can do with inexpensive things" and "Amplified gelatin fun!!" SPIE looks forward to introducing this workshop to an even larger audience in the future. The course notes for the Optics Outreach Magic Workshop (2012) are available on the Optical Society of America's (OSA) Optics For Kids web site. ${ }^{6}$ 


\section{EXPLORATIONS ON VIDEO}

One issue with faculty professional development is that workshops or courses are often offered well in advance of the time when teachers will be using the new material in the classroom. For this reason, ongoing technical support is necessary after professional development workshops. PHOTON accomplished this in part by creating videos of the 25 PHOTON Project lab experiments, showing each step of the procedure and providing additional information on the science and technology of the experiment. The "actors" in the lab videos were the project Principal Investigators, and the somewhat grainy videos were completed mostly in one take with a handheld video camera. Nonetheless they have received over 20,000 views on YouTube in the past year alone. (Videos were originally posted to Google Video, but the usage statistics for the first few years were lost when Google Video material was migrated to YouTube in 2012. The last Google Video statistics available in 2012 indicated that the Michelson Interferometer video alone had over 10,000 views.) The lab videos are posted on the PHOTON Projects YouTube Channel, www.youtube.com/user/donnellyji.

When creating the original videos for the Explorations in 2007, it was decided to use untrained student actors since they might be more appealing to a younger audience than the older and more pedantic college professors of the lab videos. It was hoped this might lead to a wider audience including both students and faculty. Video recording was completed in a conference room at the EASTCONN facility in Willimantic, CT using personal video cameras. Unfortunately, issues with lighting made some of the optical effects difficult to discern in the final videos; in fact, four of the experiments were not even attempted due to lighting difficulties. Nonetheless, the original twelve Exploration videos received thousands of views on YouTube before they were replaced by newer versions in 2012. One remaining 2007-era video, Exploring Diffraction, is still posted on the YouTube PHOTON Projects Channel and has received over 5000 views, with top viewing countries the U. S., India and the U. K. The video description includes a link to the more recent videos to help route traffic to their new location.

In the winter of 2011, OSA and NEBHE began exploring ideas to update and promote materials from the PHOTON Projects that would be appropriate for students at the middle school level and for the award-winning Optics4Kids website, www.optics4kids.org. OSA funded the development and production of sixteen new Explorations videos to be included in the Youth Education Media Library, http://www.osa.org/en-us/media library. In the previous Explorations video effort the students had neither acting nor physics experience. For the new videos, OSA (through a contract with NEBHE) hired student actors from the Communication and Theater departments of Eastern Connecticut State University in Willimantic, Connecticut. The director/videographer/editor was a senior student majoring in both departments with experience in documentary filmmaking. Professional lighting and video equipment were loaned to the project by the university and much of the production was completed in the university's J. Eugene Smith Library. (The messy experiments involving tanks of water or gelatin blocks were recorded in the home of one of the authors.) Because the four young actors had no previous optics experience, many of their surprised reactions to the "magic" of the experiments was genuine. (See Figure 2.)
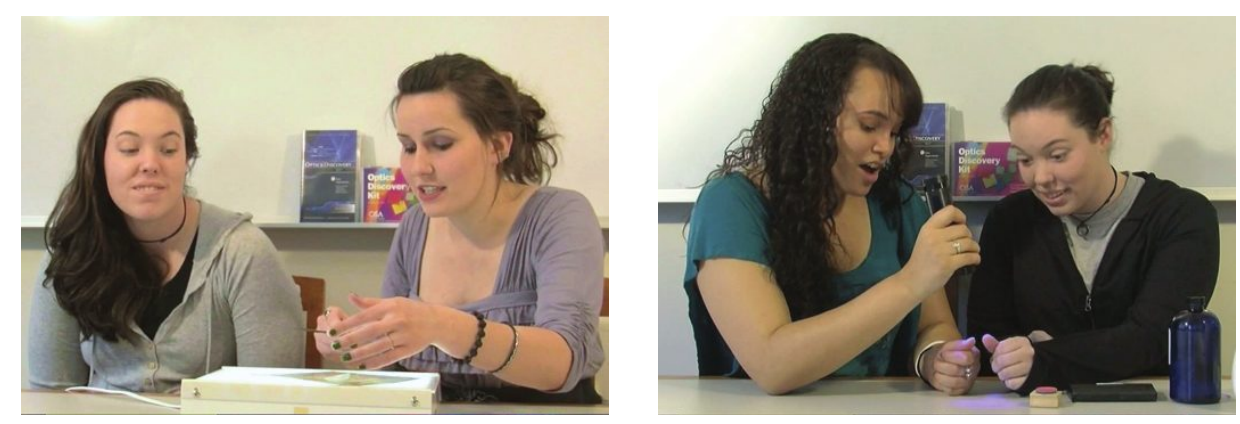

Figure 2. Actors express genuine surprise at (left) viewing cellophane shapes through crossed polarizers and (right) fluorescent ink "nail polish" viewed under ultraviolet light.

The videos were posted on YouTube for a few months in the fall of 2012 before being moved to the OSA Video Library, accumulating several hundred views in that time even with no promotion. In December 2012, a separate Youth Education category was established within the OSA Video Library and with that change a login account became a requirement to view them. Since that time, the number of views per video on the new site is fairly low. However, it was noted that when two videos were promoted on Twitter in the Optics4Kids and OSA Student Chapter feeds viewership of 
those videos increased 10-fold over that of the non-promoted videos. It is expected that when the Youth Education Media Library is added to the newly redesigned Optics for Kids web site views will increase tremendously since login will not be required.

\section{CONCLUSION}

Sixteen inquiry-based PHOTON Explorations have been developed and successfully used for the hands-on laboratories in web-based distance-learning courses and for outreach to a wide variety of student and faculty audiences. They have been recorded as a series in of short videos aimed at a middle school students available through the OSA Video Library. New Explorations will be added to the collection as time permits.

\section{ACKNOWLEDGEMENTS}

Fiber Optic Technology Education Project

Funded in part by the Advanced Technology Education program of the National Science Foundation. (NSF/DUE \#9553762) Principle Investigator, Nicholas Massa, Springfield Technical Community College: Co-Principle Investigators, Fenna Hanes, New England Board of Higher Education (Project Manager), James Masi, Western New England College, David Maack, Porta Systems, Corp

Project PHOTON: A Curriculum Development, Teacher Enhancement and Laboratory Development Project Funded in part by the Advanced Technology Education program of the National Science Foundation. (NSF/DUE \#0053284) Principle Investigator, Judith Donnelly, Three Rivers Community College; Co-Principle Investigators Fenna Hanes (Project Manager), New England Board of Higher Education, John Swienton, Exfo USA, Inc; Senior Personnel Nicholas Massa and Barbara Washburn, both Springfield Technical Community College.

Project PHOTON2: Web-based Collaborative Learning for Teachers Funded in part by the Advanced Technology Education program of the National Science Foundation. (NSF/DUE 0302528) Principle Investigator, Fenna Hanes (Project Manager), New England Board of Higher Education, Co-Pinciple Investigators, Judith Donnelly, Three Rivers Community College, Marijke Kehrhahn, Neag School of Education (University of Connecticut), Nicholas Massa and Barbara Washburn, both Springfield Technical Community College.

PHOTON PBL (Problem Based Learning)

Funded in part by the Advanced Technology Education program of the National Science Foundation. (NSF/DUE 0603143) Principle Investigator, Fenna Hanes (Project Manager), New England Board of Higher Education, Co-Pinciple Investigators, Richard Audet, Roger Williams University, Judith Donnelly, Three Rivers Community College, Nicholas Massa, Springfield Technical Community College.

\section{REFERENCES}

[1] Donnelly, J., Hanes, F. and Massa, N., " Professional development in photonics: the advanced technology education projects of the New England Board of Education," Proc. SPIE 6668, (2007).

[2] Johnson, A., Pompea, S., Arthurs, E., Walker, C. and Sparks, R., "Hands-on optics: an informal science education initiative," Proc. SPIE 6668, (2007).

[3] New England Board of Higher Education, "The PHOTON Explorations in Optics", (2010), available at www.nebhe.org/programs-overview/photon/teaching-resources

[4] Massa, N., Donnelly, J., Bell, A., Vallieres, K., and Hanes, F., "The PHOTON2 Web-Based Professional Development Model: A Year in Review," Proc. SPIE 5578, (2005).

[5] Donnelly, J. and Magnani, N., "Optics Outreach Magic Course Notes, 2012", available at http://www.optics4kids.org/osa.o4k/media/optics4kids/SPIE-2012-Outreach-Magic-doc.pdf 